Bull. Geol. Soc. Finland 41, 65-69 (1969)

\title{
FERROAN WODGINITE FROM ANKOLE, SOUTH-IWEST UGANDA
}

\author{
Oleg v. Knorring *, Th. G. Sahama** and Mart'ti Lehtinen ** \\ * Dept. of Geology, Leeds University, U. K. \\ ** Dept. of Geology, University of Helsinki, Finland
}

\begin{abstract}
Well formed crystals of ferroan wodginite occur in the pegmatite called 'Nyanga 2' in Ankole, Uganda. The crystals invariably represent penetration twins. The unit cell parameters are: $a_{0}=9.48 \AA, b_{0}=11.42 \AA, c_{0}=5.12 \AA$, $\beta=90^{\circ} 30^{\prime}$. Space group: $C 2 / c(C c)$. The separation of the doublets $221-221$ and $222-222$ is less pronounced than in the manganoan varieties of wodginite described in literature. The wodginite crystals contain inclusions of tapiolite. Microprobe analyses of the wodginite and of the tapiolite inclusions are given.
\end{abstract}

\section{Occurrence}

Pegmatites are found in south-west Uganda within the aureoles of metamorphic argillites surrounding dome-like granite-gneiss bodies of the so-called arena type. The pegmatites may therefore be considered as exterior according to the classification proposed by Gevers (1936). Sometimes they also occur within the granites, yet always close to their margins. An apparent concentration of mineralized pegmatites is found some 15-20 kms south-west of the township of Ntungamo in the southern Ankole province. Here, in an area bounded by four closely set granite-gneiss bodies, the Rukungiri, Ntungamo, Rushenyi and Lugalama arenas, a number of pegmatites occur which have been mined for beryl, columbite, cassiterite and amblygonite during the past twenty years. Apart from one distinct lithium pegmatite at Rwemeriro (v. Knorring, 1962), most of the pegmatites in this field are rather similar in composition, having a more or less prominent quartz core with an intermediate zone of muscovite greisen and kaolinized feldspar. These pegmatites are generally conformable with the enclosing garnetstaurolite schists which are strongly tourmalinized at the contacts.

The mica in the pegmatites in often closely associated with the quartz cores and appears to be of at least two kinds. The major mica zone next to the quartz is usually coarse-grained, light-yellowish muscovite. The other mica variety is finer in texture and distinctly greenishyellow, forming discordant veins and irregular pockets in the intermediate zone. Frequently there is also a selvage of muscovite within the schist close to the contact. In some pegmatites 
he muscovite is mineralized and may contain disseminated grains of columbite, wodginite, tapiolite and cassiterite.

The mineral ferroan wodginite to be described in this paper comes from a pegmatite known as Nyanga 2. This pegmatite has a prominent quartz core and smaller quartz lenses. The intermediate muscovite zone consists of muscovite with a little quartz and completely kaolinized feldspar. So far, only niobium-tantalum minerals have been recovered, first from the eluvium and later from the pegmatite. Large aggregates of columbite up to $200 \mathrm{kgs}$ in weight have been found to occur at the footwall core margin, between the quartz and the mica greisen. In addition, columbite, tapiolite and ferroan wodginite are also disseminated in the greenish-yellow muscovite greisen.

Both columbite and wodginite contain intergrowths of tapiolite and zircon. Minute crystals of tapiolite commonly project from the crystal surfaces of the ferroan wodginite, giving it a frosty appearance.

It is difficult to distinguish between columbite, tapiolite and wodginite in the muscovite greisen. There is, however, a tendency for tapiolite to be associated with quartz grains in the greisen and the Nyanga ferroan wodginite of detrital origin is readily recognized by its distinct arrow head shaped habit.

On a visit by the first two authors to some of the Ankole pegmatites in Uganda in 1967, the owner of the Nyanga mine, Mr. G. René, very generously gave a number of the wodginite crystals for a mineralogical laboratory study. The results obtained are presented in this paper.

\section{Crystal form and twinning}

The crystals found are elongated parallel to the $b$-axis and range from a few millimeters to $3 \mathrm{~cm}$ in length. The habit of the crystals is illustrated in Fig. $1 \mathrm{~A}$ with the common faces

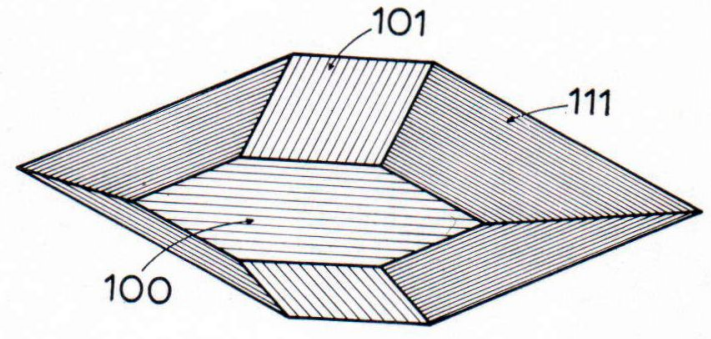

A

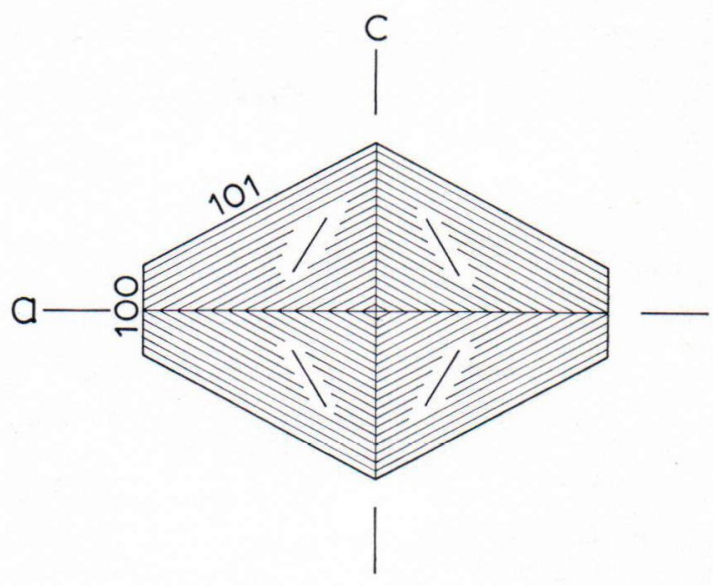

B

Fig. 1. Penetration twin of wodginite from the pegmatite Nyanga 2, Ankole, Uganda. A. Crystal habit. B. Section parallel to (010) showing traces of optic axial planes.

(100), (101) and (111). In a couple of crystals poorly developed traces of (310) were detected. The faces (010), (110) and (241), reported for the Rwanda wodginite by Bourguignon and Mélon (1965), were not observed in the Nyanga mineral. The crystals invariably represent penetration twins in the way shown in Fig. $1 \mathrm{~B}$. The twinning is easily recognized microscopically in both transmitted and reflected light. The boundary between the two individuals can be seen with a pocket lens in the middle of the face (100) as a faint line running parallel to the 
$b$-axis. Polysynthetic twinning such as that described by Vorma and Siivola.(1967) for the Sukula wodginite was not observed in the Nyanga mineral. According to personal communication with Dr. Vorma, the polysynthetic twinning in the Sukula mineral is possibly a result of a phase transformation, the material originally having crystallized in some other form (columbite?). The Crystal habit and the penetration twinning of the Nyanga mineral indicates an original crystallization in the wodginite structure and, accordingly, no polysynthetic twinning is to be expected.

\section{X-ray crystallography}

The powder pattern (Philips Norelco, filtered $\mathrm{Cu}$ radiation, Si standard) is very similar to that reported by Nickel et al. (1963) and will not be reproduced here. As was remarked by these authors, the powder pattern of wodginite closely resembles that of columbite making a distinction between columbite and wodginite rather difficult. For wodginite the weak line 200 (relative intensity $=10$ ) with $d=4.73 \AA$ is unique. This line is forbidden for both columbite and ixiolite. The best lines for identifying wodginite are, however, the two doublets $\overline{2} 21-221$ and $\overline{2} 22-222$ which are represented by single lines in the orthorhombic columbite and ixiolite powder patterns. The doublet $\overline{2} 21-221$ is strong and appears on the chart of the Nyanga mineral as an unresolved broad line. By counting the intensity across the line in steps of $2 \Theta=0.02^{\circ}$ the two lines may be separated from each other. The doublet $\overline{2} 22-222$ is weak, but is more easily separated. The following data illustrate the separation of the lines of these two doublets for the Nyanga wodginite:

$\begin{array}{ccccc}b k l & & { }^{2 \Theta_{\mathrm{Cu}}} & \mathrm{d}_{\text {meas. }} & \mathrm{d}_{\text {calc. }} \\ \overline{2} 21 \ldots \ldots \ldots \ldots \ldots \ldots \ldots & 30.00 & 2.979 & 2.981 \\ 221 \ldots \ldots \ldots \ldots \ldots \ldots & 30.17 & 2.962 & 2.962 \\ & & & & \\ \overline{2} 22 & \ldots \ldots \ldots \ldots \ldots \ldots & 43.02 & 2.101 & 2.103 \\ 222 \ldots \ldots \ldots \ldots \ldots \ldots & 43.29 & 2.089 & 2.090\end{array}$

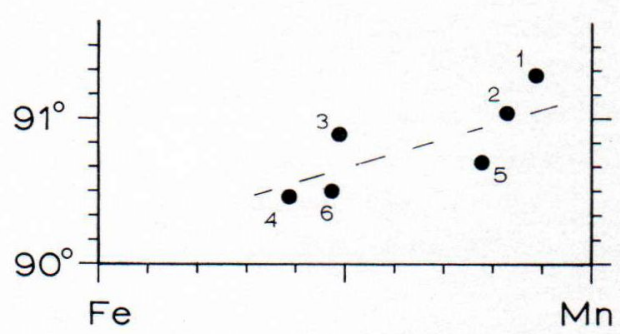

Fig. 2. Wodginite. $\beta$-angle of the unit cell plotted against the $\mathrm{Fe} / \mathrm{Mn}$ ratio.

1. Wodgina, Australia.

2. Bernic Lake, Manitoba.

3. Muhembe, Rwanda.

4. Sukula, Tammela, Finland (anal. 4).

5. Sukula, Tammela, Finland (anal. 6).

6. Nyanga 2, Ankole, Uganda.

The separation of the doublets depends on the $\beta$-angle. As has been pointed out by Bourguignon and Mélon (1965) and by Vorma and Siivola (1967), the value for the $\beta$-angle seems to increase slightly with the decrease of the $\mathrm{Fe} / \mathrm{Mn}$ ratio. On the basis of the data available so far, the relationship between the $\beta$-angle and the $\mathrm{Fe} / \mathrm{Mn}$ ratio is diagrammatically illustrated in Fig. 2. It is likely that, for the pure iron end member of the wodginite series, the $\beta$-angle is close to $90^{\circ}$. In cases in which the indentification of the mineral by powder pattern is not unequivocal or not possible at all, the identification must be made on single crystal $\mathrm{X}$-ray data.

A series of precession photographs about all three crystallographic axes of the Nyanga mineral revealed a monoclinic symmetry with the space group $C 2 / c(C c)$. The unit cell dimensions measured from the single crystal photographs and refined from the powder pattern are:

$$
\begin{aligned}
& a_{o}=9.48 \pm 0.01 \AA \\
& b_{o}=11.42 \pm 0.01 \\
& c_{o}=5.12 \pm 0.01 \\
& \beta=90^{\circ} 30^{\prime} \pm 10^{\prime}
\end{aligned}
$$

\section{Physical properties}

In thin splinters the wodginite material is transparent with a deep reddish color and weak 
pleochroism. Streak dark brown. The transparency is too poor for accurate determination of the optical constants. The mineral is optically biaxial with the optic axial plane parallel to the b-axis (Fig. 1 B). The extinction angle $\beta \wedge a=$ ca. $30^{\circ}$. The position of the optic axial plane is in accordance with the monoclinic symmetry of the mineral. The penetration twins exhibit marginal zoning.

The density measured with a Berman balance on a couple of pieces of wodginite seemingly free from tapiolite inclusions was found to be 7.2. This value compares with 7.5 calculable on the basis of the chemical composition and unit cell volume of the mineral. The low density found is probably due to invisible silicate inclusions inside the pieces used.

\section{Chemical composition}

Because the tapiolite inclusions could not be removed from the wodginite material, both minerals were analyzed separately by microprobe (Geoscan, Cambridge Instrument Co.). The results are summarized in Table 1 . The following cations in both wodginite and tapiolite were tested by microprobe and not found: $\mathrm{Ca}$, $\mathrm{Sc}, \mathrm{Zr}, \mathrm{W}$, rare earths. The table reveals that the Nyanga wodginite represents an iron-rich variety of the mineral very similar to that from Sukula given by Vorma and Siivola (1967, anal. 4).

\section{TABle 1}

Composition of wodginite and of its tapiolite inclusions from the pegmatite Nyanga 2, Ankole, Uganda. Microprobe analyses by Jaakko Siivola.

\begin{tabular}{|c|c|c|c|c|c|}
\hline & $\begin{array}{l}\text { Wod- } \\
\text { ginite } \\
\%\end{array}$ & $\begin{array}{r}\text { Tapiolite } \\
\text { inclusions } \\
\%\end{array}$ & & $\begin{array}{c}\text { Unit ce } \\
\mathrm{O}=32 \\
\text { Wod- } \\
\text { ginite }\end{array}$ & $\begin{array}{l}\text { based on } \\
\mathrm{O}=12 \\
\text { Tapiolite }\end{array}$ \\
\hline $\mathrm{Ta}_{2} \mathrm{O}_{5}$ & 68 & 81 & $\mathrm{Ta}$ & 7.79 & 3.46 \\
\hline $\mathrm{Nb}_{2} \mathrm{O}_{5}$ & 7.7 & 6.5 & $\mathrm{Nb}$ & 1. 47 & 0.46 \\
\hline $\mathrm{TiO}_{2}$ & 2.3 & 1.5 & $\mathrm{Ti}$ & 0.73 & 0.18 \\
\hline $\mathrm{SnO}_{2}^{2}$ & 8.6 & 0.5 & $\mathrm{Sn}$ & 1.44 & 0.03 \\
\hline $\mathrm{FeO}^{2}$ & 6.7 & 13 & $\mathrm{Fe}$ & 2.35 & 1.71 \\
\hline $\mathrm{MnO}$ & 6.0 & 0.6 & $\mathrm{Mn}$ & 2.15 & 0.08 \\
\hline Total & 99.3 & 103.1 & & 15.93 & 5.92 \\
\hline
\end{tabular}

The two first examples of wodginite found in Nature, Wodgina and Bernic Lake, were highly manganoan varieties of the mineral with the atomic ratios $\mathrm{Fe}: \mathrm{Mn}$ roughly $1: 8$ and $1: 5$, respectively (Nickel et al., 1963). Later finds of the mineral, Rwanda (Bourguignon and Mélon, 1965), Sukula (Vorma and Siivola, 1967) and Nyanga (this paper), have shown that Mn may be largely replaced by Fe. The most iron-rich wodginite known so far is that of Sukula (anal. 5 and 6) with an atomic ratio Fe: Mn roughly $3: 1$. Following the view expressed by Vorma and Siivola (op. cit., p. 183), there is no need to introduce any new mineral name for the hypothetical iron end member of the wodginite series. The name wodginite should be extended to cover also the Fe-rich members of the series.

The oxidation state of iron in natural wodginite was not determined for the Wodgina, Bernic Lake and Rwanda minerals. The Sukula mineral was analyzed by microprobe only and, accordingly, a distinction between ferrous and ferric iron could not be made. The oxidation state of iron in the Nyanga wodginite was tested chemically by the first author. The test was made on material containing some tapiolite inclusions and yielded $0.68 \% \mathrm{Fe}_{2} \mathrm{O}_{3}$ and $6.44 \% \mathrm{FeO}$ which corresponds to $7.05 \%$ total iron as FeO. The small amount of ferric iron is probably a result of secondary oxidation. The Nyanga mineral is a ferroan wodginite, not a ferric one. This fact is in contrast to the result from synthetic materials obtained by Turnock (1966) according to which wodginite may contain ferric but not ferrous iron. As has been remarked by Vorma and Siivola (op. cit.), synthetic phases with wodginite structure (Turnock, op. cit.; Moreau and Tramasure, 1965; Schröcke, 1966) have been obtained on compositions which do not correspond to those of the analyzed natural Fe-rich wodginite specimens. The stability field of the monoclinic wodginite structure with a composition corresponding to that of the natural Fe-rich mineral is unknown. Accordingly, the statement that a crystallization of the minerals 
of the wodginite series requires high oxygen pressure will need further verification.

The synthetic works referred to above have shown that the monoclinic wodginite structure can be prepared free from Sn and, accordingly, a content of $\mathrm{Sn}$ is not essential for the mineral. So far, however, no examples of natural wodginite are known which would be free from $\mathrm{Sn}$. For the Rwanda mineral, Bourguignon and Mélon (op. cit.) state that the Sn content found is largely due to cassiterite inclusions, but they do not exclude the possibility that a part of the $\mathrm{Sn}$ is contained in the wodginite structure itself. The effect of the Sn content, generally characteristic of natural wodginite, upon the stability of the mineral is unexplored.

In addition to the wodginite localities mentioned in this paper, Luna (1965) reports one brown grain of wodginite from a pegmatite at Krasonice (Western Moravia). Qualitative spectroscopic analysis and the $\beta$-angle of the unit cell calculated from the $\mathrm{X}$-ray powder pattern indicate that the mineral is highly manganoan. Also the $\mathrm{Sn}$ content is considerable.

\section{Tapiolite inclusions}

The tapiolite which occurs as inclusions in the wodginite penetration twin crystals at Nyanga 2 was identified by X-ray powder pattern indicating the mineral to be of the ordered trirutile type with $a_{o}=4.75 \pm 0.005 \AA$ and $c_{o}=9.18 \pm 0.01 \AA$. In reflected light under the microscope the strongly birefringent mineral shows common twinning, often in a poly synthetic development. In thin splinters the mineral is transparent with a deep reddish color and strong pleochroism. No fixed orientation with respect to the wodginite host structure was observed. The chemical composition of the tapiolite inclusions in wodginite (Table 1) compares with that of the separate twinned crystal aggregates of tapiolite found in another pegmatite near Nyanga 2 and reported by v. Knorring (1965). The wodginite phase of the Nyanga 2 mineral is considerably more rich in $\mathrm{Sn}$ and $\mathrm{Mn}$ than is the tapiolite phase.

Acknowledgment - The authors are indebted to Mr. Jaakko Siivola for the microprobe analyses.

\section{REFERENCES}

Bourguignon, P. et Mélon, J. (1965) Wodginite du Rwanda. Ann. Soc. Géol. de Belg., T. 88, p. 291.

Gevers, T. W. (1936) Phases of mineralization in Namaqualand pegmatites. Trans. Geol. Soc. S. Africa, vol. 39, p. 331.

v. Knorring, Oleg (1962) Some observations on the mineralogy of pegmatites in Uganda. 6th Ann. Rept. Res. Inst. African Geol. Univ. Leeds, p. 11.

v. Knorring, Oleg (1965) Niobium-tantalum Minerals. 9th Ann. Rept. Res. Inst. African Geol. Univ. Leeds, p. 43.

LUNA, JAN (1965) Wodginite and columbite-tantalite from a pegmatite at Krasonice (Western Moravia). Acta Univ. Carolinae, Geologica No. 3, p. 157.

Moreau, J. et Tramasure, G. (1965) Contribution a l'étude des series columbite-tantalite et tapiolitemossite. Ann. Soc. Géol. de Belg., T. 88, p. 301.
Nickel, E. H., Rowland, J. F. and McAdam, R. C. (1963) Wodginite - a new tin-manganese tantalate from Wodgina, Australia, and Bernic Lake, Manitoba. Canadian Miner., vol. 7, p. 390.

Schröcke, Helmut (1966) Über Festkörpergleichge wichte innerhalb der Columbit-Tapiolitgruppe, sowie der Columbit-Tapiolitgruppe mit YTi(Nb,Ta) $\mathrm{O}_{6}$, Euxenit, und mit $\mathrm{FeNbO}_{4}$. N. Jahrb. Min. Abh., Bd. 106, S. 1.

Turnock, A. C. (1966) Synthetic wodginite, tapiolite and tantalite. Canadian Miner., vol. 8, p. 461.

Vorma, Atso and Sirvola, JAAkкo (1967) Sukulaite $\mathrm{Ta}_{2} \mathrm{Sn}_{2} \mathrm{O}_{7}$ - and wodginite as inclusions in cassiterite in the granite pegmatite in Sukula, Tammela in SW Finland. C. R. Soc. géol. Finlande, No. 39, p. 173.

Manuscript received, August 15, 1968. 